\title{
ゾルーゲル法によるアルミニウムへの耐化学性 および親水性被覆*
}

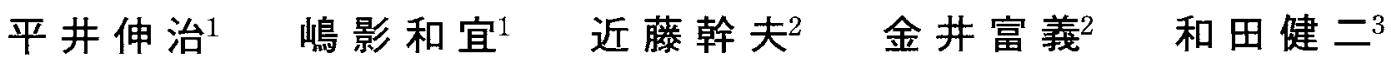

\author{
1室蘭工業大学工学部材料物性工学科 \\ 2昭和アルミニウム株式会社小山製造所 \\ 3無機材質研究所
}

J. Japan Inst. Metals, Vol. 64, No. 3 (2000), pp. 195-201

(C) 2000 The Japan Institute of Metals

\section{Chemical Corrosion Resistance Coating on Aluminum Substrates by the Sol-Gel Process}

\author{
Shinji Hirai ${ }^{1}$, Kazuyoshi Shimakage ${ }^{1}$, Mikio Kondo ${ }^{2}$, Tomiyoshi Kanai ${ }^{2}$ and Kenji Wada ${ }^{3}$ \\ ${ }^{1}$ Department of Materials Science and Engineering, Faculty of Engineering, Muroran Institute of Technology, Muroran 050-8585 \\ ${ }^{2}$ Showa Aluminum Co., Oyama Works, Oyama 323-0811 \\ ${ }^{3}$ National Institute for Research in Inorganic Materials, Tsukuba 305-0044
}

To improve the corrosion resistance to salt, acid and strongly alkaline attack, a sol-gel film using zirconium tetra- $n-$ butoxide as a starting material has been coated directly on the surface of alıminum substrates via repeating one or twice dipcoating process. The heat treatment at $573 \mathrm{~K}$ or the UV-irradiation at ambient temperature was performed for forming dense coating films after the dipping-withdrawing of aluminum substrate into the sol. Zirconium oxide films were prepared on aluminum surface by these sol-gel processes. The coating films formed on the smooth aluminum substrates under UV-irradiation indicated excellent corrosion resistance for salt, acid and alkaline attack tests. For example, the surface area of the coating film corroded for $3600 \mathrm{ks}$ in salt attack test decreased in the order of sol-gel coating film $<$ chromate film $<$ boehmite film and the sol-gel coating film had the best corrosion resistance. The coating films prepared on the coarse aluminum substrate by a boiling treatment after the heat treatment at $573 \mathrm{~K}$ also had greater corrosion resistance and appeared water-avid surface having contact angle of approximately $3^{\circ}$.

(Received August 30, 1999, In Final Form January 12, 2000)

Keywords: zirconium oxide, aluminum substrate, sol-gel process, ultraviolet irradiation, corrosion resistance, salt, acid and alkaline attack tests, water-avid surface

\section{1. 緒言}

クロメート法は，アルミニウムに耐食性を付与する塗装下 地処理として熱交換器用部品などに広く用いられている。 かし，米国では1988年6月にカリフォルニア州でクロムメ ッキ拈よびク口ム酸了ルマイト工場からの大気中への 6 価 クロム放出の規制を目的とする法律である“South Coast Air Quality Management District Rule 1169”が成立1)して以 来, 今日では全米規模でEPA(Environmental Protection Agency) や OSHA (Occupation Safety \& Health Agency) $K$ より、ミストとして排出される 6 価クロムが厳しく規制さ れ，ヨーロッパではクロメート処理品を排除する動きすらあ る $^{2)}$ そこで，ク口ム以外の金属塩被覆や有機物皮覆を始め とする，クロメート法の代替処理法の開発が急務となってい 子.

筆者らは，ジルコニウムアルコキシドを用いたゾルーゲル 法により，未封孔のアルミニウム陽極酸化皮膜にジルコニウ ム酸化物を被覆し，細孔中をでゾルーゲル皮膜が入り込んだ

*1998年 9 月日本金属学会秋期大会に叔てて発表
陽極酸化皮膜の多孔質層と，その上のゾルーゲル皮膜の被覆 層から構成される複合皮膜の耐アルカリ性について報告して きた ${ }^{3-5)}$ ．被覆は，陽極酸化処理を施した基板のゾル中への 浸漬・引き上げから被覆によって形成されたゲル膜の緻密化 までの操作を繰り返すディップューティング法により行っ た、ゲル膜の緻密化には， $573 \mathrm{~K}$ で加熱する方法と常温で紫 外線を照射する方法6)を試攵，いずれの複合皮膜も $\mathrm{H}_{2} \mathrm{SO}_{4}$ 溶液中で作製した厚さ $20 \mu \mathrm{m} の$ 封孔後の陽極酸化皮膜と比 べて, 起電力測定試験(JIS H 8681) とよる耐アルカリ時間 が25〜66倍増加した。このような複合皮膜の酎アルカリ性 の飛躍的な増加は，クロメート皮膜のように皮膜に欠陷が生 した場合，皮膜中に残存するクロメート溶液によって皮膜が 再生されるとは別の機構7)で進行し，すなわち $\mathrm{NaOH}$ 水溶 液の複合皮膜中の侵入経路に和ける $\mathrm{Zr}(\mathrm{OH})_{4} や \mathrm{ZrO}(\mathrm{OH})_{2}$ の上5な化学的に安定な反応生成物の形成とその再溶解の重 畳による自己修復効果によるものと推定した ${ }^{3-5)}$.

本研究では基板に陽極酸化処理を施していないアルミニウ ム素材を用い,ゾルーゲル法によりジルコニウム酸化物を被 覆し, その皮膜の耐アルカリ性, 耐塩性, 耐酸性について調 查するとともに，皮膜が塗装下地処理として水性塗料が使用 
できる親水性皮膜であることを確かめるために，水に対する 濡孔性についても調査し，そのクロメート代替処理法として の可能性について調べた.

ゾルーグル法により直接素材に被覆したアルミニウムの防 食についての既往の研究では，牧島ら离がテトライソプロポ キシチタンと塩化セりウムをゾルの出発原料に用いたゾルー ゲル法により $\mathrm{CeO}_{2}-\mathrm{TiO}_{2}$ をルミニウム管に被覆し，303 $\mathrm{K} の 1 \mathrm{NHCl}$ 水溶液中で $5.4 \mathrm{ks}$ の浸漬試験から，未被覆の基 板に対する皮膜の腐食減量が26〜 75\%減少することを明ら かにした。また, SchmidtとWolter ${ }^{9)}$ はジクロロジフェニ ルシランとジクロロ(メチル)ビニルシランとトリェトキシシ ランを出発原料に用いて有機 $-\mathrm{SiO}_{2}$ 複合材料を被覆し, 323 $\mathrm{K} の 5 \% \mathrm{NaOH}$ 水溶液や $40 \% \mathrm{KOH}$ 水溶液沶よび $5 \% \mathrm{H}_{2} \mathrm{SO}_{4}$ 水溶液に対して子優孔た耐食性を有寸ることを報告してい る.また, Sugama ら ル]-4,5-ジヒドロイミダゾールとテトライソプロポキシジ ルュニウムを出発原料に用い有機 $-\mathrm{ZrO}_{2}-\mathrm{SiO}_{2}$ 複合材料を被 覆し, 常温の $0.5 \mathrm{M}$ 食塩水中に扣けるアノード分極測定か ら被覆の優れた防食效果を確認している．Kato ${ }^{11)}$ はトッ トキシシランを出発原料に用い $\mathrm{SiO}_{2} を$ 被覆し, $323 \mathrm{~K}$ にて $122.4 \mathrm{ks}$ に及ぶCASS 試験(JIS H 8681)から，未被覆の》 ルミニウム基板の腐食面積が30\%であるのに対し，皮膜の 腐食面積は $0.02 \sim 0.05 \%$ まて減少することを確認した。ささ 飞, 皮膜の厚膜化を目的とした研究としては，トリセカンダ リーブトキシアルミニウムを用いて作製したゾル中に浸基板 と対極とを浸漬し，その間に電圧を印加され，強制的にアル ミニウム基板にゾルを泳動・電着させる電気泳動電着法によ り，厚さが $110 \sim 300 \mu \mathrm{m}$ に達する維密な $\mathrm{Al}_{2} \mathrm{O}_{3}$ 皮膜の形 成 ${ }^{12)}$ に関する報告がある。この他, Zheng ら ${ }^{13)}$ はゾルーゲル 法による有機 $-\mathrm{Al}_{2} \mathrm{O}_{3}$ 複合材料を被覆し，その耐塩性，塗料 密着性，耐摩耗性の評価からクロム酸電解浴を用いた陽極酸 化処理法の代替法として可能性を示唆している.

本研究では，これまでに主にステンレス鋼の耐酸性14-16) や耐高温酸化性16-18)の改善を目的として被覆されてきたジ ルコニウム酸化物をアルミニウムの防食に応用するため, 出 発原料にテトラノルマルブトキシジルコニウムを出発原料炕 用い，これまでにアルミニウム陽極酸化皮膜の耐アルカリ性 の飛羅的な向上が確認されたゾルを用いてアルミニウム基板 に直接被覆し，防食効果に及ぼす基板表面粗さ，ゲル膜の故 密化処理拉よび被覆後の沸騰水処理の效果などについて検討 を行った。

\section{2. 実 験 方 法}

化学組 成 か 99.13 mass $\% \mathrm{Al} ， \quad 0.13$ mass $\% \mathrm{Si} ， 0.57$ mass $\% \mathrm{Fe}, 0.12 \operatorname{mass} \% \mathrm{Cu}$ の厚さ $0.5 \mathrm{~mm}$ のアルミニウム板 (A1100)から $100 \times 50(\mathrm{~mm})$ に切り出したるのを基板として 用いた．基板の表面は，\#80，\#600，\#1000，\#1500の耐水

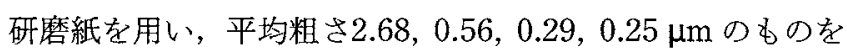
用意し，末た，未研磨で王延傷が残る $0.20 \mu \mathrm{m}$ のるのを用 いた。

ゾルは, 試薬のテトラノルマルブトキシジルュニウム $(\mathrm{Zr}$
純度 : 99.99 mass \%)，ジェチレングリコール(水分 : 0.1 mass\%以下), 脱水エタノール (水分 : 0.005 mass\%以下) 用い，既報3-5) と同様の方法により調整した。 また，ゾルの

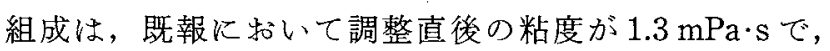
$345.6 \mathrm{ks}$ の熟成後に特いても $2 \mathrm{mPa}$. を超えない長期安定 性を有することが確認されたモル比でテトラノルマルブトキ シジルコニウム：ジェチレングリコール：水：脱水エタノー ル $=1: 2: 2: 500$ るを用いた。

被覆は基板をゾルル浸漬し，一定速度で引上げ，大気中 $0.3 \mathrm{ks}$ 放置する乾燥, 酸素雲团気中 $573 \mathrm{~K}$ にて $1.2 \mathrm{ks}$ 加熱, または同し酸素雾囲気中常温にて $1.2 \mathrm{ks}$ 紫外線を照射する 操作を 1 2 回繰り返すディップューティング法により行っ た.な拉、ディップコーティング法の場合, 1 回のコーティ ング当たりに形成される皮膜の厚さ $(h)$ は，重力加速度に $g$

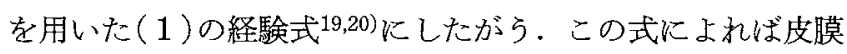
厚さは，ゾルの粘度 $(\eta)$ と基板の引き上げ速度 $\left(U_{0}\right)$ の増加と ともに憬くなり,一方, ゾルの表面張力 $\left(\gamma_{\mathrm{LV}}\right)$ と密度 $(\rho)$ の増 加とともに薄くなる。

$$
h=0.94\left(\eta U_{0}\right)^{2 / 3} / \gamma_{\mathrm{L}}^{1 / 6}(\rho g)^{1 / 2}
$$

本研究では基板の引上げ速度を, 加熱処理の場合は $3 \mathrm{~mm}$. $\mathrm{s}^{-1}$, 紫外線照射の場合は $1 \mathrm{~mm} \cdot \mathrm{s}^{-1}$ とし, 紫外線照射の場 合は1回のコーティング当たり膜厚を薄くした。加熱処理 の場合，基板上に被覆された乾燥ゲル膜中から残留有機物を 酸化によって $\mathrm{CO}_{2}$ や $\mathrm{H}_{2} \mathrm{O}$ とてて除去することにより皮膜の

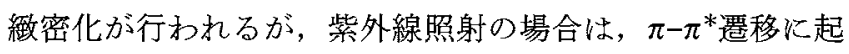
因したアルキル基-O 結合の切断と $\mathrm{Zr}-\mathrm{O}$ 結合の形成により 緻密化が進行していると推定される ${ }^{6)}$. 低生水銀ランプから 発生した紫外線(波長：254 nm と.185 nm)のうち，本研究 で使用したゾルや基板上に被覆した湿潤ゲル膜が $185 \mathrm{~nm} の$ 紫外線を吸収することがこれまでに確認されているが6)，1 回のコーティング当たり膜厚を薄くすることにより，皮膜の 内部までへの緻密化を試みた。な和，一部の試料について は, 被覆終了後に基板を沸騰水に $2.7 \mathrm{ks}$ 浸漬する沸騰水処 理を行った。

皮膜の耐食性は，pH 6.5 の 4\%食塩水を $308 \mathrm{~K}$ に保持し た試験室で $3600 \mathrm{ks}$ 噴霧する塩水噴霧試験 (JIS Z 2371), 酢酸を用いて pH 3 K調整した塩化銅（II）二水和物を含む $5 \%$ 食塩水を $323 \mathrm{~K}$ の試験室で $172.8 \mathrm{ks}$ 噴霧する CASS 試 験(JIS H 8681)の活か，10 mass\% NaOH 溶液を $308 \pm 0.5$ $\mathrm{K}$ に保たれた皮膜に接触させ，基板と溶液側の電極との間 で $1 \mathrm{mV}$ の電位が検出されるまでの時間を測定する起電力測 定試験(JIS H 8681) により評価した。な抏, 塩水噴霧試験 では耐塩性を白錆の発錆面積から求めた次のレイティングナ ンバ一(以下，R.N.)を用いて評価した．発錆が全く見られ ないものを 5 ，発錆面積が $10 \%$ 末満を $4,25 \%$ 未満を 3,50 $\%$ 未満を $2 ， 50 \%$ 以上を 1 とした.

\section{3. 結果および考察}

\section{1 基板の表面粗さが皮膜の耐塩性に及ぼす影響}

Fig. 1 Kは各表面粗さを有する基板にディップューティン グを 2 回繰り返して被覆した皮膜の塩水噴霧試験結果を示 


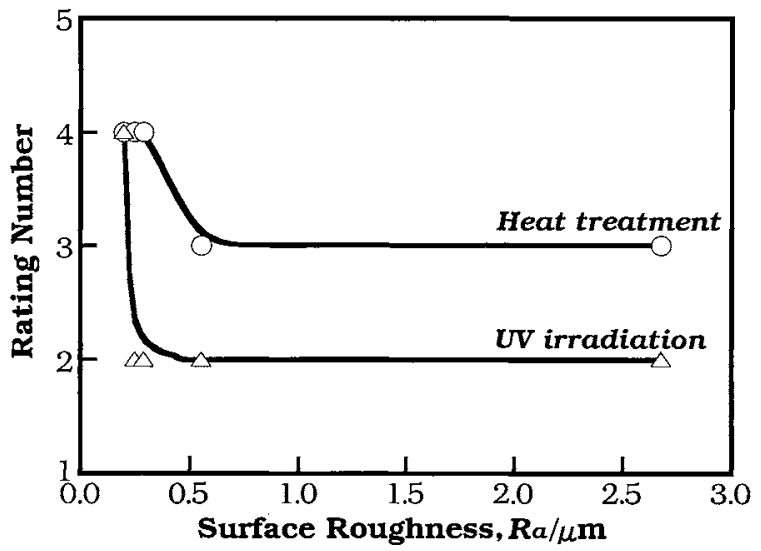

Fig. 1 Relationship between the surface roughness and the corrosion resistance to salt attack for coating films prepared by repeating twice dip-coatings.

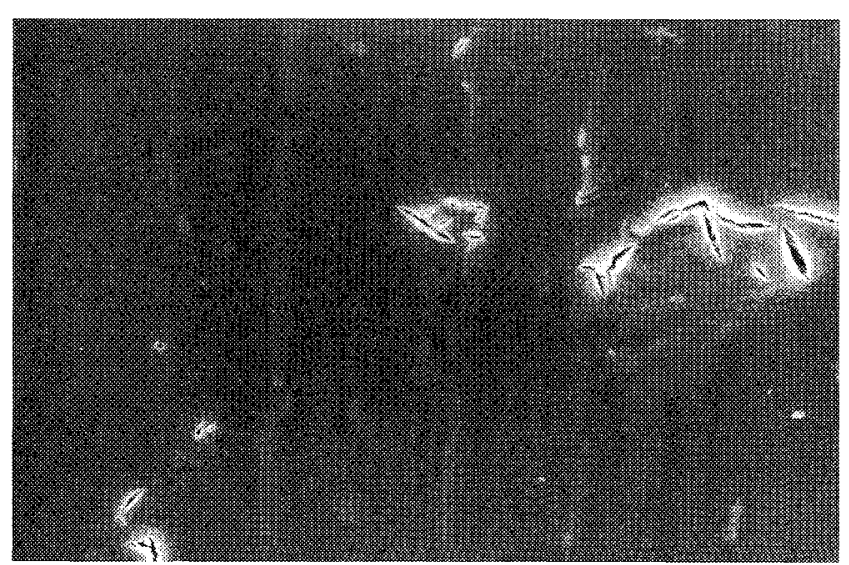

(a) $R a=0.20 \mu \mathrm{m}$

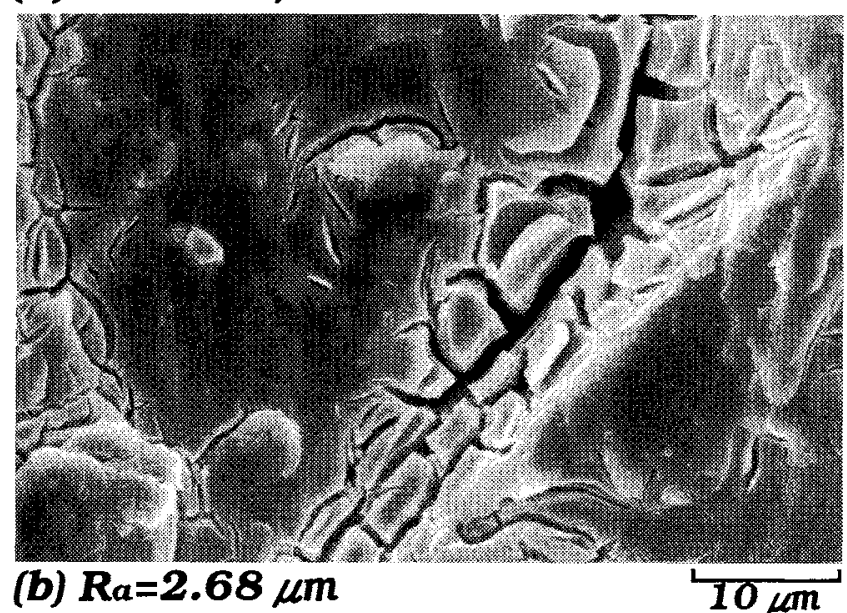

Fig. 2 SEM photographs of the surfaces of coating films. The coating films were prepared by repeating twice dip-coatings and heat treatment at $573 \mathrm{~K}$.

す. 基板の表面粗さが皮膜の耐塩性に大さく影響することが 明らかで， $573 \mathrm{~K}$ に拉ける加熱処理および常温に括ける加熱 処理のいずれの場合も粗さの増加に伴いR.N.は減少した. $573 \mathrm{~K}$ で加熱処理した平均粗さが $0.2 \mu \mathrm{m}$ と $2.68 \mu \mathrm{m}$ の基板 上の皮膜表面について FE-SEM により観察すると, Fig. 2 (a)および(b)に示すように, $0.2 \mu \mathrm{m}$ の平滑な基板の場合,

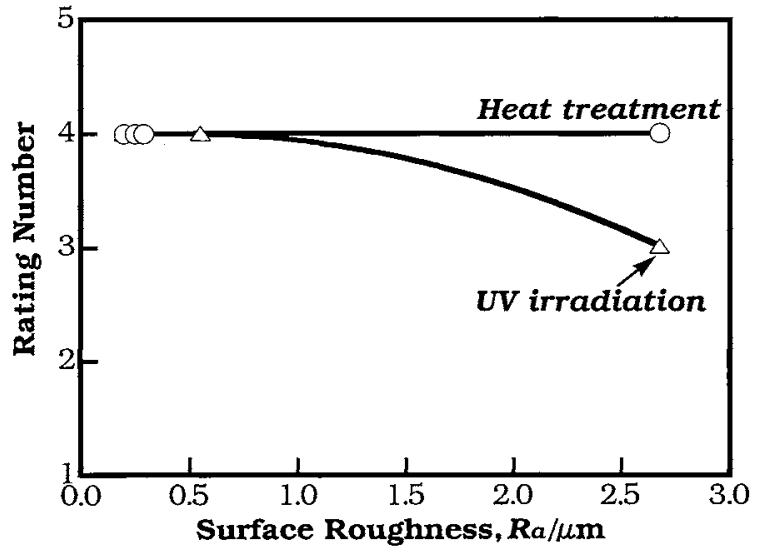

Fig. 3 Relationship between the surface roughness and the corrosion resistance to salt attack for coating films prepared by repeating twice dip-coatings and a boiling treatment.

亀裂がほとんど見られないのに対し，2.68 $\mu \mathrm{m}$ の粗い基板で は多数の亀裂が観察された。この亀裂の原因は，湿潤ゲルの 皮膜中に存在する細孔からアルコールや水の溶媒が蒸発する 際, 毛細管力に起因した皮膜表面に平行に働く引張応力が生 成することが知られているが21)，この引張応力が基板表面 の研磨傷の凸部に集中するために発生したものと推定され る. 平均粗さが $0.2 \mu \mathrm{m}$ の平滑な基板を用いて, $573 \mathrm{~K}$ で加 熱処理した場合には，コーティング回数が 1 回で, $3600 \mathrm{ks}$ の塩水噴霧試験に叔いても全く発錆が見られないR.N.5の 皮膜の形成が確認されている.

一方，常温で紫外線を照射した場合は，表面粗さが 0.2 $\mu \mathrm{m}$ の場合のみ, 加熱㚭理と変わらない良好な耐塩性を示し たが，それを超えるとR.N.は2至で咸少した。例㝋ば，平 均粗さが $2.68 \mu \mathrm{m}$ の基板上の皮膜を観察すると, Fig. 2(b) の加熱処理した皮膜よりも多数の刍裂が基板全面にわたって 観察された。この多数の亀裂が発生する原因について, 詳細 は不明であるが，加熱処理の場合は酸化反応，紫外線照射の 場合は光励起反庍火よる皮膜中からの残留有機物の分解・除 去機構の相違はるちろんのこと，紫外線照射の昜合に皮膜の 内部まで緻密化するために引上げ速度を加熱処理の場合より も遅くして皮膜を薄くしていることなどが重冨し，紫外線照 射による急激な緻密化時に，表面応力が基板のわずかな凸部 に赫いても集中したためと推察される。

\section{2 皮膜の耐塩性に及ぼす沸騰水処理の影響}

Fig. 3 には各々の表面粗さの基板にディップューティング を2回繰り返して被覆した皮膜を，さらに沙騰水中に $1.2 \mathrm{ks}$ 浸漬した皮膜の塩水噴霧試験結果を示す. Fig. 1 の沸騰水処 理前の皮膜と比較すると，加蓺処理，紫外線照射いずれの場 合も皮膜の酎塩性が基板の表面粗さにほとんど依存しなくな り，平均粗さが $2.68 \mu \mathrm{m}$ の最も粗い基板に和いても R.N.4 の比較的良好な酎塩性を示した。すなわち、アルミニウム陽 極酸化皮膜に同じ被覆と沸騰水処理を施すと, 沸騰水処理を 行っていないものと比べて耐アルカリ時間が $1.1 \sim 3.7$ 倍向上 した場合4)と同様に，耐塩性も増加することが判明した。 こ の表面粗さが $2.68 \mu \mathrm{m}$ の基板上に被覆した沸騰水処理前後 
の皮膜について FE-SEMにより観察すると，Fig. 4 に示す ようK沸騰水処理後は, 微細な析出物が隹裂の内部まで析出 していることが観察された。この析出物の形態と大きさは， 陽極酸化皮膜に同じ被覆と沸騰水処理を施したものと同じで あった．析出物の同定を行らため皮膜表面のX線回折を行 ったところ，皮膜が非晶質であることを表わすブロードな回 折ピーグ以以外の，電解研磨したアルミニウム板に浸漬した

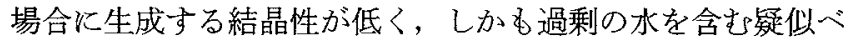
ーマイト22,23)や，その溶解と再結晶により形成されることが 報告されているバイヤライト24)のピークは検出されなかっ た。この他，FT-IR 吸収スペクトルル和いても3280,3090 と $1090 \mathrm{~cm}^{-1}$ の疑似ベーマイトやバイヤライトの吸收 ${ }^{22)}$ が 検出されていないばかりか，沸腾水処理後に拈ける新たな析 出物による吸収も検出されていない。このことから析出物 が，皮膜の亀裂部に持沙沸騰水浸漬によるアルミニウムの 溶解に起因したものではなく，広い $\mathrm{pH}$ 域の水溶液中で安定 な $\mathrm{Zr}(\mathrm{OH})_{4}$ をたは $\mathrm{ZrO}(\mathrm{OH})_{2}{ }^{25)}$ のらな子ので，高透過率 を有寸るものであると推定される。なお，ゾルーゲル皮膜の 沸騰水浸漬による析出物の生成については，アルミナ皮膜で は数十 $\mathrm{nm}$ の山凸を持つ花并状組織 ${ }^{26)}$ となることが報告され ている.

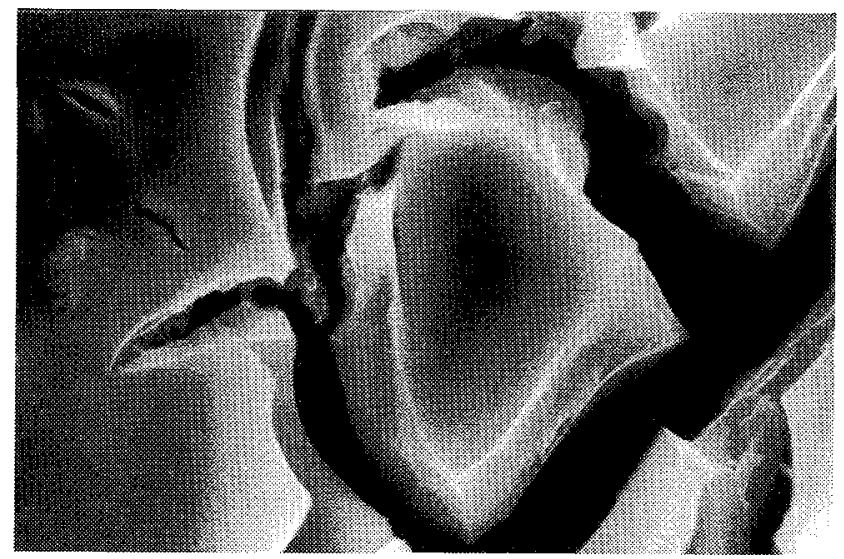

(a) Before boiling treatment

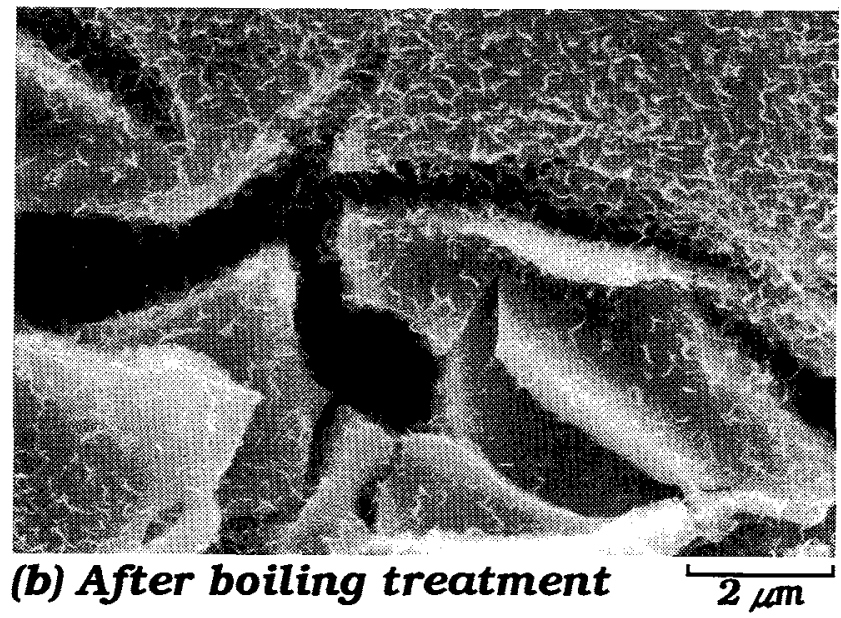

Fig. 4 SEM photographs of the surfaces of coating films before and after a boiling treatment. The coating films were formed on coarse aluminum substrate $\left(R_{\mathrm{a}}=2.68 \mu \mathrm{m}\right)$, and prepared by repeating twice dip-coatings and heat treatment at $573 \mathrm{~K}$.
このように，ゾルーダル皮膜の耐塩性は，基板の表面粗 さ，コーティング回数，加熱または紫外線照射のゲル膜の緻 密化条件，さらには沸騰水処理に依存するが，3600 ks の塩 水噴霧試験がら，今回作製した皮膜はR.N.1の無処理のア ルミニウムはもちろんのこと，R.N.2のベーマイト皮膜， R.N.3のクロメート皮膜をも疼駕する耐塩性皮膜であること が確認された。

\subsection{CASS 試験による皮膜の耐酸性}

Fig. 5 KはCASS 試験に括けるコーティング回数と基板 の腐食減量との関係を示す，基板には表面粗さが $0.20 \mu \mathrm{m}$ の平滑なアルミニウム基板を用い，腐食減量はCASS 試験 終了後, 無水ク口ム酸一リン酸系洗浄液を用いて腐食生成物 を除去し，さらに十分乾燥した基板の単位面積当たりの基板 の質量減少から求めた．腐食減量はコーティング回数ととも に減少し，2回以上で腐食減量が従来のクロメート処理材上 り为減少し，4回に和ける腐食減量を各種処理材と比較する と, 無処理のアルミニウム, ベーマイト皮膜, クロメート皮 膜，ゾルーダル皮膜(紫外線照射)，ゾルーゲル皮膜(加熱)の 順に後者注ど減少し，耐塩性と同様にゾルーゲル皮膜の優れ た耐酸性も確認された。.Fig. 6(a) 括よび(b)には，コーティ ング回数 4 回の皮膜の CASS 試験終了後，無水クロム酸-り ン酸系洗浄液を用いて腐食生成物を除いた皮膜表面および孔 食部の断面組織を示す. 基板の圧延方向に平行に孔食が観察 され，その孔食の深さは表面から約 $150 \mu \mathrm{m}$ に達している. 3.1 耐塩性試験結果の考察と同様に，湿潤ゲルから溶媒が 蒸発する際に発生する引張応力が基板表面の凸部に集中する ことにより皮膜に俥裂を生じ，そこから $\mathrm{Cl}^{-}$イオンが侵入

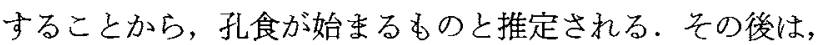
アルミニウムの孔食機構として報告されているように，アル ミニウムのアノード溶解により溶出した $\mathrm{Al}^{3+}$ イオが $\mathrm{Cl}^{-}$ イオンと結合して $\mathrm{AlCl}_{3}$ を形成し，先の加水分解により $\mathrm{pH}$ が低下し27)，孔食が拡大したものと考兄られる。

\section{4 起電力測定試験による皮膜の耐アルカリ性}

表面粗さが $0.20 \mu \mathrm{m}$ の平滑な基板を用い，乾燥ゲル膜の

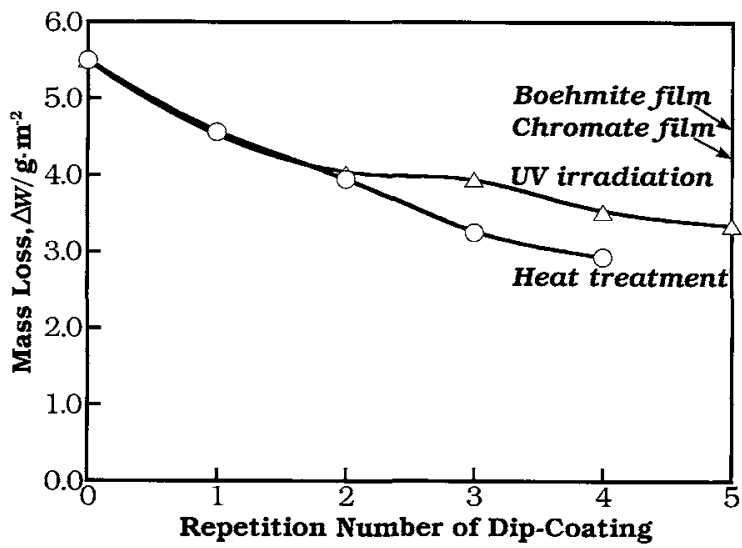

Fig. 5 Relationship between the repetition number of dipcoating and the mass loss of samples determined by the copper-accelerated acetic acid salt spray test. 

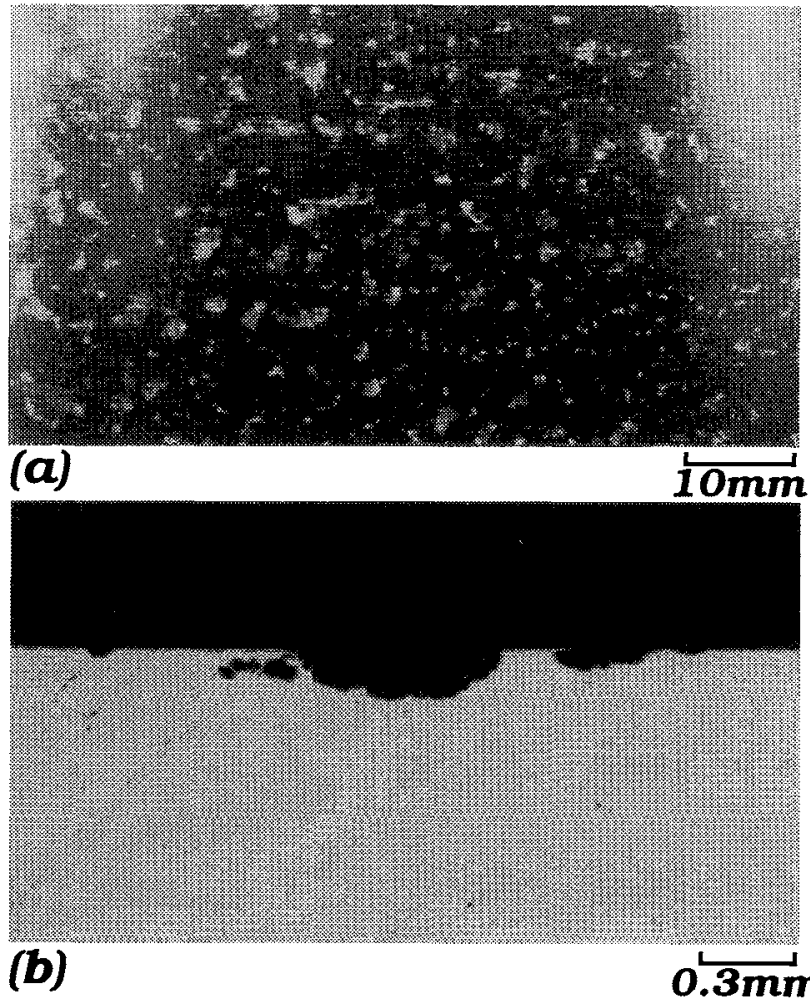

Fig. 6 Photographs of (a) the surface of coating film and (b) the cross-section of pitting formed on aluminum substrate from which the corrosion products were removed by pickling after the copper-accelerated acetic acid salt spray test. The coating films were prepared by repeating four dip-coatings and heat treatment at $573 \mathrm{~K}$.

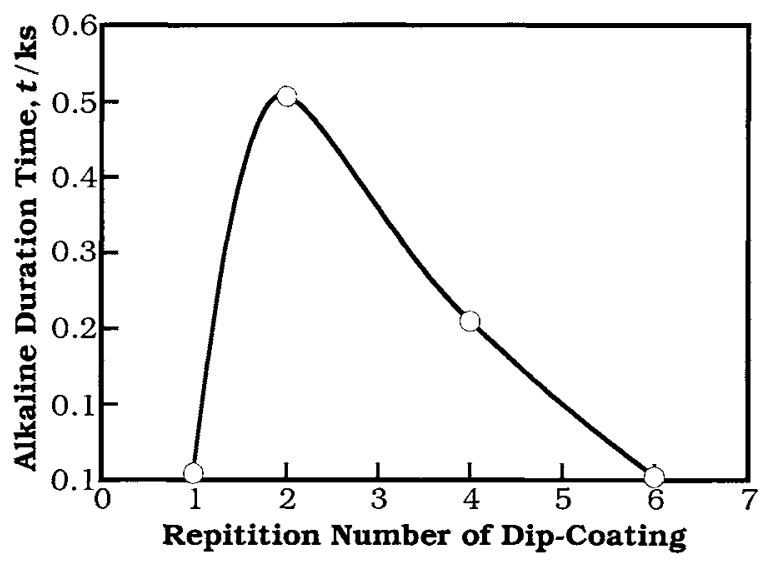

Fig. 7 Relationship between the repetition number of dipcoatings and the alkaline duration time for coating film prepared by UV-irradiation or by heat treatment at $573 \mathrm{~K}$.

㮹密化を加熱処理により行った皮膜の耐アルカリ性のコーテ ィング回数依存性を調査した。 その結果をFig. 7 に示す. ゾルーゲル皮膜の耐アルカリ時間は，コーティング回数が 2 回に打いて $\mathrm{H}_{2} \mathrm{SO}_{4}$ 溶液中で作製した厚さ $20 \mu \mathrm{m}$ の封孔後の 陽極酸化皮膜と比べて約2.7倍程度増加したが，陽極酸化皮 膜に同じ被覆を繰り返した皮膜の25～66倍の増加 ${ }^{3-5)}$ 亿は及 ばなかった。またコーティングをさらに繰り返すと耐アル カリ時間は減少した．膜厚はコーティング回数に比例して増

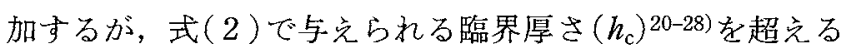
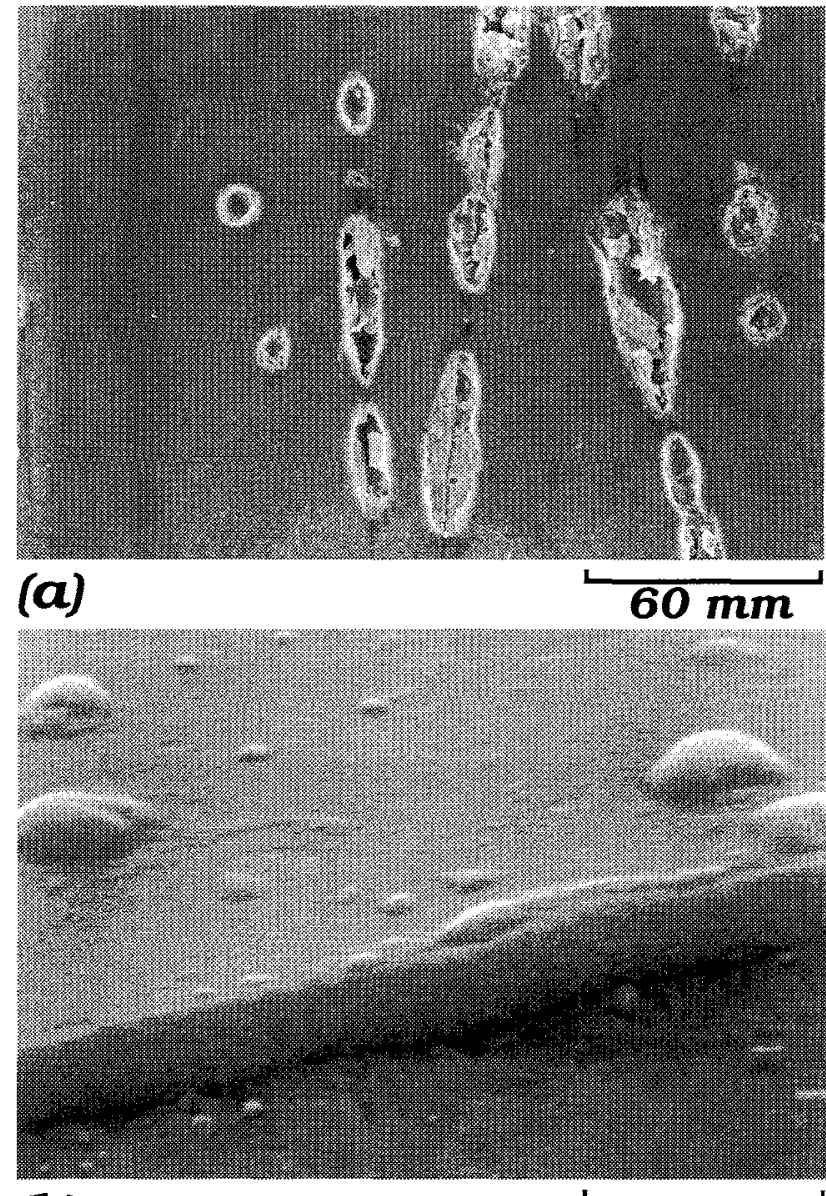

(b)

$0.3 \mu \mathrm{m}$

Fig. 8 SEM photographs of (a) the surface and (b) the fracture section of a coating film after an electromotive force measurement test. The coating films were prepared by repeating twice dip-coatings and heat treatment at $573 \mathrm{~K}$.

と, 皮膜中から溶媒の蒸発に伴って発生する引張応力 $(\sigma)$ に より，皮膜に亀裂が発生する。

$$
h_{\mathrm{c}}=\left(K_{\mathrm{IC}} / \sigma \Omega\right)^{2}
$$

ここで， $K_{\mathrm{IC}}$ は皮膜の破壞强勒値， $\Omega$ は皮膜と基板の弾性率 の相対比に依存する関数（ゲル膜では $\Omega=1$ )である. 基板に 陽極酸化皮膜を用いた場合も，コーティング回数に対する耐 アルカリ時間に最大値が存在することは確認されている 皮膜の破断面のSEM 観察によって測定した皮膜の平均膜厚 は，コーティング回数が 1, 2,3，4 回と増加するにつれて, 膜厚 $60.17,0.20,0.46,0.66 \mu \mathrm{m}$ と增加した. これらの膜厚 測定と Fig. 7 の結果から，平滑な基板に被覆する場合， $h_{c}$ が $0.20 \mu \mathrm{m}$ 付近であるものと推定される. Fig. 8 K, 耐了 ルカリ時間が最も増大したコーティング回数が 2 回の皮膜 の起電力測定試験後の表面执よび断面の FE-SEM 像を示 す。塩水噴霧試験おょび CASS 試験の場合と同様に，表面 応力に起因した基板々部に括ける皮膜の亀裂から，アルミニ ウムの溶解が進行していることが明らかである。また，腐食 部以外の正常な皮膜断面を観察すると, 皮膜が溶解により若 干薄くなっているが， $\mathrm{NaOH}$ 水溶液が基板に到達しアルミ ニウムを溶解した様子は観察されなかった。 


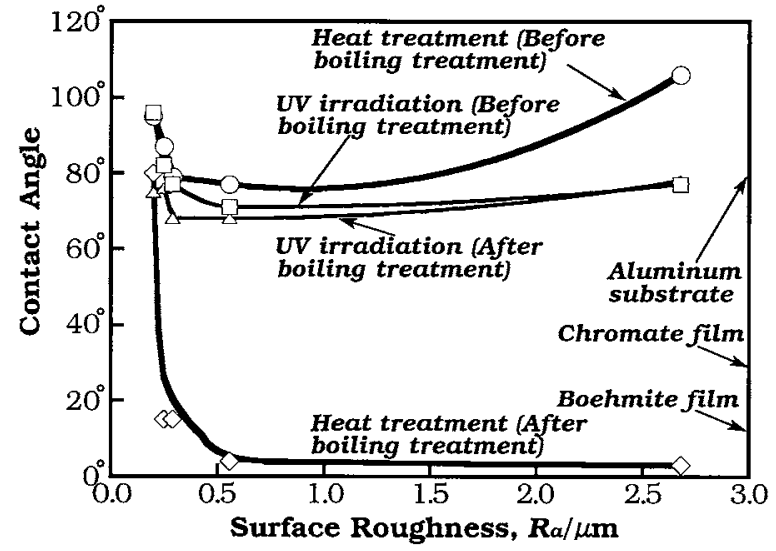

Fig. 9 Relationship between the surface roughness and the contact angle of water for coating substrates prepared by repeating twice dip-coatings.

\section{5 皮膜の水に対する濡れ性}

ゾルーゲル被覆がクロメート法の代替法となるためとは， 水性塗料方使用できる親水性皮膜であることる必要である。 Fig. 1 扣よびFig. 3 の皮膜の水に対する接触角の湘定結果 をFig. 9 亿示す. 未被覆の表面粗さが $0.20 \mu \mathrm{m}$ のアルミ ウム基板の接触角が約 $80^{\circ}$ ，ベーマイト皮膜が約 $13^{\circ}$ ，クロメ 一ト皮膜が約 $29^{\circ}$ であることから，同じ表面粗さが $0.20 \mu \mathrm{m}$ の基板上の $102^{\circ}$ 最高とするゾルーゲル皮膜の接触角は，ポ リテトラフルオロエチレン(PTFE) 皮膜に近い蹯水性を示し た.このよらなゾルーゲル皮膜の蹯水性は，ゾルの調整時に 出発原料で岁るアルコキシドを加水分解したり，さらにはコ ーティングの繰り返し回数每に湿潤げルから不要な溶媒を除 去するために十分な条件で緻密化処理を行っているにるかか わらず，皮膜中に弈水基となる未分解アルコキシ基がわずか に残存するためと推察さ机る。二つの緻密化处理を比較する と，平滑な基板の場合，同程度の蹯水性を示したが，表面粗 さの増加とともに紫外線照射上り加熱処理の方が接触角が増 加する傾向が認められた。

一方, 沸騰水に浸漬した後は， $573 \mathrm{~K}$ の加熱処理の場合の 及接触角は大きく減少し, 特に, 粗さが 0.56〜2.68 $\mu \mathrm{m}$ の 粗い基板では，接触角が $3 \sim 4^{\circ}$ まで低下し，高い親水性を示 した．表面粗さが $2.68 \mu \mathrm{m}$ の粗い基板を用い， $573 \mathrm{~K}$ とて 加熱した場合と常温で紫外線を照射した場合の沸騰水处理後 の皮膜表面の析出物を FE-SEM により詳細に観察すると，

Fig. 10 からも明らかなよう飞紫外線を照射した皮膜上の析 出物は，その端面がノコギリ状で㐫り，また全体の表面積が 大きくなる傾向が観察された。主た，加熱処理した場合は， 析出物が比較的基板に平行に析出している様子が観察され， この上らな析出物の形態は，わずか汇残存する未分解アルコ キシ基が加水分解反応にも関与しているものと推定される.

いずれの場合も，析出物がヒドロキシ基の上らな親水性を有 していることには間違いないが，ゲルの緻密化炕常温で紫外 線を照射した場合は，析出物の面積が增加していることと， 析出物と空気層との複合面の形成により，表面の濡れ性が表 面の形状に大きく支配29)されたため，親水性が発現されな

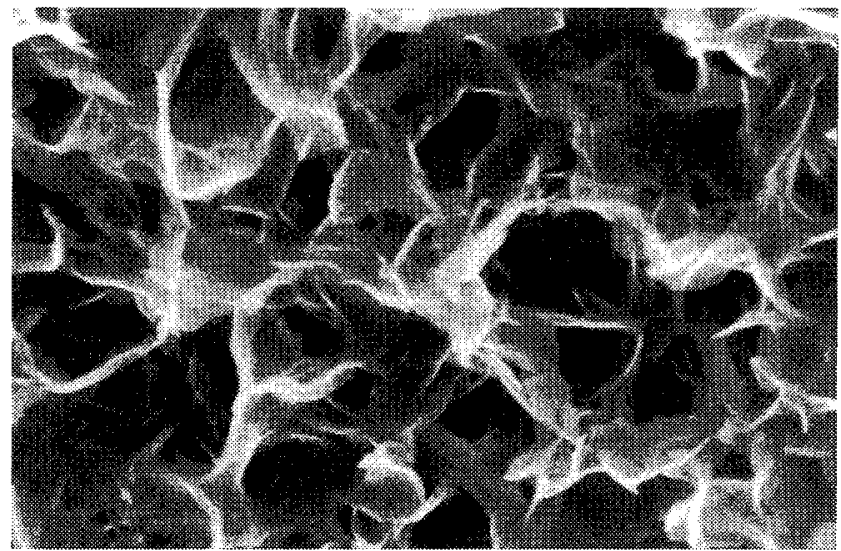

\section{(a)}

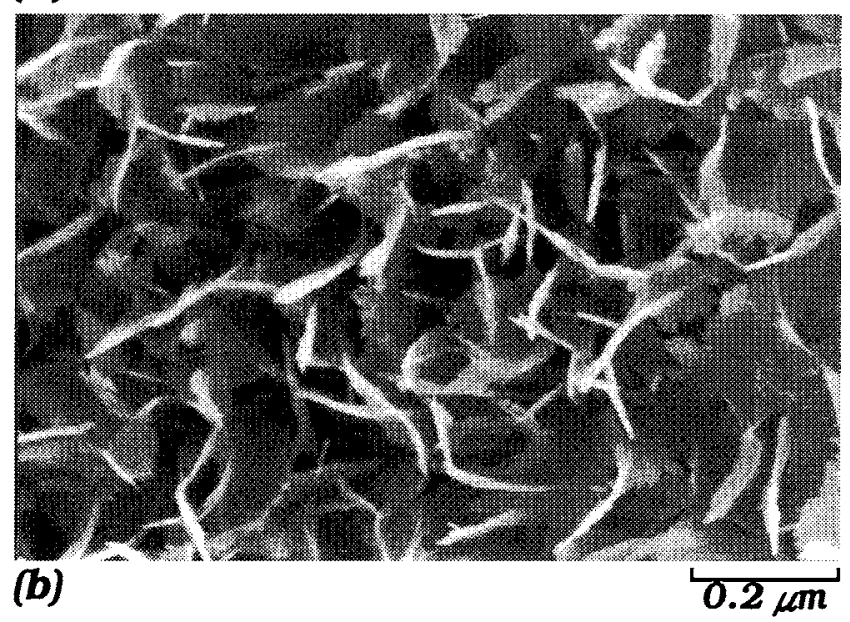

Fig. 10 SEM photographs of the surfaces of coating films formed on coarse aluminum substrates $\left(R_{\mathrm{a}}=2.68 \mu \mathrm{m}\right)$ by a boiling treatment after (a) heat treatment and (b) UV irradiation. The coating films were prepared by repeating twice dip-coating.

かったすのと推定される。

\section{6 ゾルーゲル被覆のクロメート代替法としての可能性}

皮膜の密着性や耐摩耗性など未解決の部分も残るが，テト ラノルマルブトキシジルュニウムを出発原料に用いたゾルー ゲル皮膜は，耐食性和よび親水性に叔いて，クロメート皮膜 を度駕する皮膜であることが判明した．表面粗さが $0.56 \mu \mathrm{m}$ までの平滑な基板を用い，常温の紫外線照射により維密化を 行い，さらに沸騰水処理を施した皮膜は，耐食性に優れ，ま た $0.56 \sim 2.68 \mu \mathrm{m}$ の粗い基板を用い， $573 \mathrm{~K}$ の加熱処理に より緻密化を行い，沸騰水処理を施した皮膜は，耐食性のみ ならず水性塗料に対する親水性にも優れていた。

しかし，これらの被覆をク口メートの代替とするために は，加熱処理の場合には，さらに加熱温度を下げる必要があ り，紫外線照射の場合には，親水性を発現させるために照射 条件の詳細な検討や，複雑形状の基板にも照射を可能にする ため基板を回転させるなどの照射方法の検討も必要である。 この他，ゾル有機溶媒を使用するため作業環境の問題や， ゾルのアルコキシドが高価であるという問題も残るが，耐食 性や親水性はクロメート皮膜を凌ぐことは確固たる事実であ り，今度，装飾性，耐摩耗性など新たな特性が確認されれ 
ば，ゾルーゲル被覆が代替処理法の一つになりらる可能性が あると考觉られる。

\section{4. 結言}

本研究ではテトラノルマルブトキシジルコニウムを用いた ゾルーゲル法により, 直接アルミニウム素材へのジルコニウ 么酸化物被覆を試み，その皮膜の耐食性と水に対する濡水性 について検討した. 得られた結果は以下のよらに要約される.

(1) 塩水噴霧試験の結果, 加熱処理, 紫外線照射いずれの 場合も，基板の表面粗さの増加とともに発錆が進行したのに 対し，沸騰水処理を施した場合，発錆は表面粗さに依存しな くなり，最も粗い $2.68 \mu \mathrm{m} の$ 基板に执いても発錆面積が 10\%に満たない良好な耐塩性を示した。

(2) CASS 試験では，加熱処理，紫外線照射いずれの昜合 もコーティング回数が 2 回以上で，皮膜の腐食減量が従来 のクロメート処理材よりも減少し, 優れた耐酸性を示すこと がおかった。

（3）起電力測定試験による皮膜の耐アルカリ時間は，コー ティング回数が 2 回に和いて, $\mathrm{H}_{2} \mathrm{SO}_{4}$ 電解浴中で作製した 厚さ $20 \mu \mathrm{m}$ の封孔後の陽極酸化皮膜と比べて約 2.7 倍まで増 加した。

（4）基板の水に対する接触角を測定したところ, 沸騰水处 理前は, 加熱処理, 紫外線照射いずれの場合る表面粗さに依 存することなく70 9 $90^{\circ}$ 付近のはっ水性を示し，紫外線照射 の場合は，沸騰水処理後に和いてもはっ水性を示した。一 方, 加熱処理の場合の接触角は大きく減少し, 特に粗さが 0.56〜2.68 $\mu \mathrm{m}$ の粗い基板では接触角が約 $3^{\circ}$ まで低下し, 超 親水性の発現が認められた。

（5）表面粗さが $0.56 \mu \mathrm{m}$ までの平滑な基板を用い，常温 の紫外線照射により緻密化を行い，さらに沸騰水処理を施し た皮膜は耐食性に優れ，尔た $0.56 \sim 2.68 \mu \mathrm{m}$ の粗い基板を 用い, $573 \mathrm{~K}$ の加熱処理により緻密化を行い, その後, 沸騰 水処理を施した皮膜は，耐食性のみならず水性塗料に対する 親水性にも優れていることが判明した。
文献

1) K. Takada: ALUMINIUMU-KENKYUKAISHI, 4(1992), 14.

2) D. Matsuura: J. Surface Finishing Soc. Japan, 49(1998), 215220 .

3) S. Hirai, S. Aizawa, K. Shimakage and K. Wada: J. Japan Inst. Metals, 59(1995), 547-553.

4) S. Hirai, K. Shimakage, S. Aizawa and K. Wada: J. Am. Ceram. Soc., 81 (1998), 3087-3092.

5) S. Hirai, K. Shimakage and K. Wada: Materia Japan, 34(1995), $1185-1187$.

6) S. Hirai, K. Shimakage, M. Sekiguchi, K. Wada and A. Nukui: J. Am. Ceram. Soc., 82(1999), 2011-2016.

7) T. Aoe: J. Surface Finishing Soc. Japan, 49(1998), 221-229.

8) A. Makishima, M. Asami and K. Wada: J. Non-Cryst. Solid, 100 (1988), 321-324.

9) H. Schmidt and H. Wolter: J. Non-Cryst. Solid, 121(1990), 428-435.

10) T. Sugama, N. Carciello and M. Miura: Thin Solid Films, 216 (1992), 249-258.

11) K. Kato: J. Mater. Sci., 28(1993), 4033-4036.

12) D. Clark, W. Daizell and D. Folz: Ceram. Eng. Sci. Proc., 9(1988), 1111-1118.

13) H. Zheng, Y. Du, M. Damron, J. Wright and M. Tang: Metal Finishing, (1998), 35-38.

14) M. Shane and M. Mecartney: J. Mater. Sci., 25 (1990), 15371544.

15) M. Atik, C. 'Kha, P. Neto, L. Avaca, M. Aegerter and J. Zarzycki: J. Mater. Sci. Lett., 14(1995), 178-181.

16) M. Atik and M. Aegerter: J. Non-Cryst. Solid, $147 \& 148$ (1992), 813-819.

17) K. Izumi, M. Murakami, T. Deguchi, A. Morita, N. Tohge and T. Minami: J. Am. Ceram. Soc., 72(1989), 1465-1468.

18) K. Miyazawa, K. Suzuki and M. Wey: J. Am. Ceram. Soc., 78(1995), 347-355.

19) L. Landau and B. Levich: Acta Physicochimica U.R.S.S., $17(1942), 42-54$.

20) C. Brinker, A. Hurd, P. Schunk, G. Frye and C. Ashley: J. Non-Cryst. Solids, 147\&148(1992), 424-436.

21) S. Sakka: ZOLU-GERUHOU-NO-KAGAKU, AGUNESYOOFUUSYA, (1988), 35-45.

22) W. Vedder and D. Vermilyea: Trans Faraday Soc., 65(1969), $561-584$.

23) A. Pierre and D. Uhlmann: J. Am. Ceram. Soc., 70(1987), 2328.

24) P. Bowen, J. Highfield, A. Mocellin and T. Ring: J. Am. Ceram. Soc., 73(1990), 724-728.

25) A. Paul: J. Mater. Sci., 12(1977), 2246-2268.

26) A. Yuasa, H. Inaba, K. Tadanaga, M. Tatsumisago and T. Minami: Proc. XVII International Congress on Glass, 4(1995), 445-449.

27) A. Evans, M. Drory and M. Hu: J. Mater. Res., 3(1988), 1043-1049.

28) G. Itoh: J. Japan Inst. Light Metals, 31(1981), 683-696.

29) H. Saito and H. Takazawa: J. Surface Finishing Soc. Japan, $47(1996), 558-561$. 